\title{
The post-war Bosnia and Herzegovina: Social capital and pro-social behaviour
}

\begin{abstract}
ADNAN EFENDIC
School of Economics and Business, University of Sarajevo, Trg Oslobodjenja A.I. 1, 71000 Sarajevo, Bosnia and Herzegovina

Received: October 19, 2018 • Revised manuscript received: October 18, 2019 • Accepted: November 28, 2019

(c) 2020 Akadémiai Kiadó, Budapest

ABSTRACT

This paper investigates how social capital contributes to the pro-social behaviour of individuals in a postconflict environment. I simultaneously investigate the pro-social behaviours in the periods of crisis (floods) and normality and observe whether (structural and relational) social capital has important influences in these two different times. The main novelty of this approach is that I model individuals' pro-social behaviours jointly for both the periods in focus and treat them as systematic outcomes of observed and unobserved (endogenous) influences. I find that more pro-social activities in the normal times are positively associated with such activities in the crisis period. Additionally, the results reveal the importance of (structural) social capital on pro-social behaviour - namely, group membership, size and ethnic structure of individual networks matter. Of particular interest for this post-conflict society and related literature is that greater ethnic diversity of individual networks is supportive for pro-social engagement of citizens. Finally, among the observed economic influences, I find that the respondents working in the informal economy report more pro-social activities while formal employment works more as financial intermediary for these engagements.
\end{abstract}

\section{KEYWORDS}

social capital, pro-social behaviour, post-conflict environment, crisis, normality

\section{JEL CLASSIFICATION INDICES}

017, R20, Z13

E-mail: adnan.efendic@efsa.unsa.ba 


\section{INTRODUCTION}

Bosnia and Herzegovina $(\mathrm{BiH})$ is a well-known country, unfortunately, due to the war which lasted for four years between 1992 and 1995, and involved ethnically motivated violence. The war led to more than 100,000 lives being lost, and around 50\% of its citizens being internally and externally displaced. Two decades later, reconciliation of society is still a salient issue. In May 2014, the country was affected with unforeseen floods, similar to which had not been seen in the modern history of this region. Within one day, most of the country was under water, with landslides destroying whole villages. Surprisingly, only a few lives were lost, thanks to the functional institutional response, but even more thanks to the citizens who organised themselves in a day, and managed to save lives and wealth. For the first time, this country witnessed the importance of its social capital and a hope that this post-conflict society, where the conflict has an ethnic background, has 'the tie that binds' (UNDP 2009) diverse people living together in this society. During the flood period, 'ethnic boundaries' between people became less relevant.

$\mathrm{BiH}$ has been classified as a country with low-levels of social capital (Hakansson - Sjoholm 2007; UNDP 2007, UNDP 2009; Whitt 2010) and ethnic tolerance (Dyrstad 2012). Yet, during the flood period, people started acting together to help out others, not just their neighbours or family, but people on the other side of the country to whom they had no relations. This event inspired my research, and thus, I investigate whether social capital matters in explaining these engagements, including, in particular, the role of ethnic diversity of individual networking. I conduct this investigation by hypothesising that more social capital is associated with a greater engagement of citizens in this post-conflict society in both normal and crisis periods. The research relies on representative survey data collected in 2015 with over 6,000 respondents.

I conceptualise social capital as a multi-dimensional phenomenon that can affect different socioeconomic outcomes (e.g. pro-social activity of individuals, economic well-being, economic growth

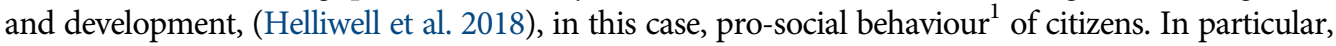
I am interested in the role of social capital as networking - in terms of size and structure - and norms - in terms of trust - in affecting pro-social activity of citizens in times of crisis and normality. This kind of investigation is linked to Portes (1998), where the argument is that social capital is a feature of social organizations, such as networks, norms and trust that facilitate cooperation.

The paper is organised as follows. After the introductory part, Section 2 provides literature review and theoretical background for the research. In Section 3, I explain the empirical approach, survey design, how I measure pro-social behaviour and social capital and report descriptive statistics of the variables of interest. Empirical analysis based on the probability models is explained in Section 4, which includes modelling procedure and discussion of the obtained results. Penultimate Section 5 reports some of the limitations of this study, while the final section concludes.

\section{SOCIAL CAPITAL - A MULTI-DIMENSIONAL CONSTRUCT}

Social capital has been put forward as crucial building block of society which can influence institutional efficiency, economic development, well-being, crime rates and incidences of other

\footnotetext{
${ }^{1}$ Note that I use interchangably the terms pro-social behaviour, pro-social activity and pro-social engagement with the same meaning explained in Section 2.
} 
social and environmental problems (Helliwell et al. 2018; Lesage - Ha 2012; Putnam 2000). A higher level of social capital is argued to improve political stability, enhance factor productivity and social integration (e.g. Knack - Keefer 1997; Kaasa 2009; Lease - Ha 2012; Ostrom 2001; Rose 1999). Pro-social behaviour is an action which is taken with the intention to improve the situation of another person or persons whereby the actor is not motivated by the fulfilment of professional obligations (Bierhoff 2002). Pro-social activities provide also psychological benefits, supported by emotions and higher life evaluations beyond material awards (Helliwell et al. 2018). It can be considered as one of the defining characteristics of humans, which plays a vital role in maintaining social bonds in one society (Bosancianu et al. 2013).

Social capital has been highly contested field of the research due to its vague definitions, poorly measured data, empirical strategies used to identify the causal effect, and the mixing of functional and causal concepts of social capital (e.g. Durlauf 2002; Robison et al. 2002; Sobel 2002). Definitions and conceptualisations of social capital have been proliferated, stemming from several foundational works (Bourdieu 1980; Coleman 1988; Burt 1992; Putnam 2000). A common feature of all these views is that the core element of social capital remains relations to people, interactions and approach to resources, while the differences exist mainly in the conceptualisation and interpretation of the social capital in relation to individuals, networks and social structures.

The previous discussion implies that social capital means different things to different people (Dasgupta - Seragelding 2002) and I present some examples how social capital has been interpreted in the literature. Adler - Kwon (2002: 17) define social capital as 'the goodwill that is engendered by the fabric of social relations and that can be mobilised to facilitate action.' Sobel (2002) describes social capital as circumstances in which individuals can use membership in groups and networks to secure benefits. Robison et al. (2002: 19) see social capital as 'a person's or groups' sympathy toward another person or group that may produce a potential benefit, and preferential treatment for another person or group or persons beyond that expected in an exchange relationship.' Yet, as Coleman (1988) points out, social capital is not one entity, but a variety of different entities, while Serageldin - Grootaert (1999) propose an integrated view of more types of social capital to measure the effects of social capital. I adopt this approach that social capital is best understood as a multidimensional phenomenon (Serageldin - Grootaert 1999; Durlauf 2002; Efendic et al. 2015; Grootaert et al. 2004; Helliwell et al. 2018; Rebmann et al. 2017), where structural and relational dimensions of social capital coexist (Granovetter 1992; Nahapiet - Ghoshal 1998; Savioli - Patuelli 2016) and impact pro-social activity of individuals.

I categorise social capital into two main dimensions. The first one is structural social capital which is observed most often through networks (Coleman 1988; Efendic et al. 2015; Grootaert et al. 2004; Putnam 1995; Woolcock 1998). Structural social capital reflects 'the overall pattern of connections between actors - that is, who you reach and how you reach them' (Nahapiet Ghoshal 1998: 244), i.e. the number, types and configurations of network ties. The second is often referred to as the relational dimension of social capital, 'those assets created and leveraged through relationships,' i.e. norms, such as trust and expectations of trustworthy behaviour. Without going into this conceptual discussion, for the purpose of this study I refer to Nahapiet Ghoshal's (1988) work and their term 'relational' dimension of social capital, which captures trust. Accordingly, I investigate the effects of structural and relational dimensions of social capital on pro-social behaviour, which could be understood as a behaviour full of goodwill facilitated by social capital (Adler - Kwon 2002; Gootaert et al. 2004).

The research on post-disaster recovery implies that pro-social behaviour, such as collective action, has the potential to overcome lack of economic resources, assistances from national and 
international agencies, and can decrease the level of damage facilitating post-crisis reconstruction (Aldrich 2012; Dabrowski - Myachenkova 2018). Pro-social behaviour can therefore serve as an 'informal insurance' during or after disasters and help in overcoming societal problems by stimulating the recovery on the neighbourhoods or community-based networks (Aldrich 2010). To the contrary, in normal times these elements might directly limit access to social capital given that the participation in associations and networks depends largely on one's resources and social status (Sopha 2007). As a particular novelty of this research I intend to investigate if the prosocial activities in typical and crisis period are associated (either in positive or negative direction) or probably not. Moreover, to my knowledge, there is no research which investigates the effect of social capital, with particular focus on ethnic diversity of networking, on pro-social behaviour, simultaneously for both the situations, crisis and normality.

\section{EMPIRICAL APPROACH, DATA AND METHODOLOGY}

Structural social capital (networks and patterns of connections) in our empirical strategy are used as a social capital dimension (Grootaert et al. 2004) that affects pro-social behaviour of individuals. Simply said, memberships in groups and networks in the context of size and structure are tools that are used to obtain knowledge and information, provide access to different types of resources and facilitate actions (Efendic - Ledeneva 2020); they are intermediaries that individuals use in a series of regular or emergency situations. If we accept this argument, there is a reasoning to include membership in groups and networks as explanatory variables of pro-social behaviour. In the empirical investigation, I include the influences of the size of individual networks, individual membership in associations, and the structure of the networks, including the strength of ties (strong versus weak ties) and ethnic diversity of networks (homogenous or diverse). While much of these influences have been covered in the existing literature (e.g. research from the Western Balkans region on the role of network size and structure by Rebmann et al. 2017; or on the strength of network structure, e.g. Granovetter 1973; Greve - Salaff 2003; Wang - Altinay 2012) the effect of ethnic diversity of individual networking in a post-conflict society remains rather an unexplored issue, which motivates our deeper investigation.

Inter-ethnic networking is likely to play a role in the social outcomes (Edwards et al. 2006) and individuals who are friends with individuals from different ethnicity are more likely to have stronger forms of social capital (UNDP 2009). Given this and based on the earlier findings in the economic literature (e.g. Efendic et al. 2015; Efendic - Pugh 2018) I use survey data to analyse the effect of ethnic diversity of networks on individual pro-social activity in this post-conflict society. In the existing literature, ethnic diversity has been investigated mainly in the framework of ethnic heterogeneities caused by migration and inflow of different cultures and traditions into formerly homogenous areas. This is motivated by the fact that ethnic diversity is increasing in the most advanced countries and driven mostly by sharp increases in immigration (Putnam 2007). This research treats the consequences of a change in the opposite direction - namely, a shift towards homogenisation in much of $\mathrm{BiH}$ - which is something new, being enforced largely exogenously by violence (Malcolm 1996). In such circumstances I expect that the respondents having more ethnically diverse networks will be more pro-socially active on the ground in both the crisis and normal periods. 
When comes to the relational social capital, I also include more dimensions of trust generalised trust (i.e. trust in unknown people from general public), local trust (trust in local people) and institutional trust (trust in institutions, i.e. functioning of institutional environment). In most of the literature, trust represents a fundamental dimension of social capital (Bourdieu 1980, 1986; Portes 1998; Putnam 2000; Alder - Kwon 2002; Grossman 2013; Savioli Patuelli 2016), and individual actions are therefore shaped, redirected, constrained, among others, by the interpersonal trust, social networks and organisations (Coleman 1988). The effect of trust on social activities of citizens might be both positive and negative. That depends mainly whether it produces positive externalities or competence, intensions or control (Nooteboom 2007). Finally, I examine the relationship between employment and pro-social behaviour. $\mathrm{BiH}$ is a country where over $30 \%$ of workforce is formally unemployed while 30 per cent is working in the informal economy. Linked to this, I aim to investigate how economic performance of individuals (i.e. formal and informal employment) affects the pro-social behaviour.

The empirical part of the paper is based on primary data collected in Bosnia and Herzegovina. There are 6,021 randomly selected respondents ${ }^{2}$ who were surveyed over the period of June-August 2015. The survey was conducted via computer-assisted telephone interviewing (CATI) using landline numbers. The telephone database used for this survey had almost one million active numbers. The sample is representative of 138 out of 143 municipalities in $\mathrm{BiH}$. Five municipalities did not participate in the survey because there were not enough telephone numbers available in the database. These municipalities are among the smallest ones with a few hundred citizens. The survey was designed so that each municipality should have at least 40 participants and at least 6,000 respondents in total. The survey data are used to construct relevant variables for our empirical investigation, which I introduce with abbreviations and short explanations in Table 1.

The aim of this analysis is to better understand the determinants of the pro-social behaviour of citizens in the periods of crisis (crisis) ${ }^{3}$ and normality (normality), and if these two engagements are mutually associated. I measure this according to whether individuals have worked to help others in their community in typical time or in response to the crisis (floods). I measure pro-social behaviour in a non-crisis period by asking the respondents:

'In the last year, have you helped anyone outside of your house for free?'

to which they may respond YES or NO. Around $60 \%$ of the respondents reported that they provided some support to others for free.

The crisis period that is used as a reference period was the flood period in $\mathrm{BiH}$, which occurred 13-18 May 2014, when major part of the country was under floods for a week, with hundreds of landslides spreading the damage across urban and rural areas. Public

\footnotetext{
${ }^{2}$ The technique of random selection by closest birthday was used to implement the survey. On first contact, the interviewees were asked about the number of persons living in one apartment or house between 16 and 65 years old. The interviewers conducted the interview with a selected household member whose birthday was closest to the date they are interviewing. If that person was not at home, they arranged call-backs, if possible. The software schedules the call-backs five times before omitting the number. This method ensures a random selection of the respondents. In the final dataset, there are 44 observations per municipality, on average. The minimum number of observations per municipality is 40 and the maximum is 46 .
}

${ }^{3}$ Note that from here on I use italics to denote abbreviations of the variables used in the model. 
Table 1. Descriptive statistics of the main variables of interest

\begin{tabular}{|c|c|c|c|c|}
\hline Variables & Description & $\begin{array}{c}\text { Number of } \\
\text { observations }\end{array}$ & Mean & $\begin{array}{c}\text { Do not knows/na, } \\
\%\end{array}$ \\
\hline \multicolumn{5}{|c|}{ Pro-social behaviour - dependent variables } \\
\hline Normality & $\begin{array}{l}\text { Helping others for free in the last year: } \\
0=\text { no; } 1=\text { yes }\end{array}$ & 5,963 & 0.61 & 1.0 \\
\hline Crisis & $\begin{array}{l}\text { Helping others during the floods: } \\
0=\text { no; } 1=\text { yes }\end{array}$ & 5,981 & 0.70 & 0.7 \\
\hline \multicolumn{5}{|c|}{ Social capital - relational and structural - independent variables } \\
\hline Group & Member of any group: $0=$ No; $1=$ Yes & 5,997 & 0.13 & 0.4 \\
\hline Contsized & $\begin{array}{l}\text { Size of the networks: } 0=0-9 \text { persons; } \\
1=10 \text { and over }\end{array}$ & 5,144 & 0.55 & 14.6 \\
\hline Ethncont & Other ethnicity in network: $0 \%-100 \%$ & 4,566 & 12.23 & 24.2 \\
\hline Strongtie & $\begin{array}{l}\text { Strong networks - family, friends: } \\
0-100 \%\end{array}$ & 4,626 & 36.90 & 23.2 \\
\hline Weaktie & $\begin{array}{l}\text { Weak - acquaintances, other: } 0-100 \% \\
\text { (base) }\end{array}$ & 4,626 & 13.10 & 23.2 \\
\hline Gentrust & $\begin{array}{l}\text { Generalised trust in people: } 1 \text { - no trust } \\
\text { to } 5 \text { - max. trust }\end{array}$ & 5,853 & 1.36 & 2.9 \\
\hline Muntrust & $\begin{array}{c}\text { Generalised trust in local people: } 1 \\
- \text { no trust to } 5 \text { - max. trust }\end{array}$ & 5,807 & 1.57 & 3.6 \\
\hline Insttrust & $\begin{array}{l}\text { Institutional trust: } 1 \text { - no trust to } 5 \\
\text { - max. trust }\end{array}$ & 5,284 & 1.69 & 12.2 \\
\hline \multicolumn{5}{|c|}{ Socio-demographic and individual characteristics - independent variables } \\
\hline Age & Age of respondents: $16-65$ years & 6,021 & 47.10 & 0.0 \\
\hline Male & Gender: $0=$ female; $1=$ male & 6,021 & 0.45 & 0.0 \\
\hline Educat & $\begin{array}{l}\text { Education: } 0=\text { no and primary; } \\
1=\text { secondary and high }\end{array}$ & 5,993 & 0.71 & 0.5 \\
\hline Femploy & $\begin{array}{l}\text { Employed in formal sector: } 0=\text { no; } \\
1=\text { yes }\end{array}$ & 6,004 & 0.27 & 0.3 \\
\hline Infemploy & $\begin{array}{l}\text { Employed in informal sector: } 0=\text { no; } \\
1=\text { yes }\end{array}$ & 5,996 & 0.26 & 0.5 \\
\hline Outoflabour & $\begin{array}{l}\text { Outside of the labour force: } 0=\text { no; } \\
1=\text { yes (base) }\end{array}$ & 6,021 & 0.38 & 0.0 \\
\hline Incomeper & $\begin{array}{l}\text { Personal income: } 0=\text { below average; } \\
1=\text { average/above }\end{array}$ & 5,164 & 0.49 & 14.3 \\
\hline
\end{tabular}


Table 1. Continued

\begin{tabular}{|l|l|c|c|c|}
\hline Variables & \multicolumn{1}{|c|}{ Description } & $\begin{array}{c}\text { Number of } \\
\text { observations }\end{array}$ & Mean & $\begin{array}{c}\text { Do not knows/na, } \\
\%\end{array}$ \\
\hline Urban & Urban area: $0=$ no; $1=$ yes & 6,021 & 0.28 & 0.0 \\
\hline Suburban & Suburban area: $0=$ no; $1=$ yes & 6,021 & 0.24 & 0.0 \\
\hline Rural & $\begin{array}{l}\text { Rural area: } 0=\text { no; } 1=\text { yes } \\
\text { (base category) }\end{array}$ & 6,021 & 0.48 & 0.0 \\
\hline Fbih & $\begin{array}{l}\text { Entity in BiH: } 0=\text { other; } \\
1=\text { Federation BiH }\end{array}$ & 6,021 & 0.57 & 0.0 \\
\hline Rsbih & $\begin{array}{l}\text { Entity in BiH: } 0=\text { other; } 1=\text { Republika } \\
\text { Srpska }\end{array}$ & 6,021 & 0.42 & 0.0 \\
\hline Dbbih & $\begin{array}{l}\text { District in BiH: } 0=\text { other; } 1=\text { District } \\
\text { of Brcko (base) }\end{array}$ & 6,021 & 0.01 & 0.0 \\
\hline Mixed & $\begin{array}{l}\text { Ethnic diversity of neighbouring area: } \\
0=\text { other; } 1=\text { mixed }\end{array}$ & 5,831 & 0.31 & 3.2 \\
\hline
\end{tabular}

Note: The variables insttrust is a factor variable, which includes aggregation of trust in institutions at the national, entity and municipality levels. The Factor and Cronbach's alpha analysis supported this strategy.

infrastructure was destroyed and hundreds of thousands of citizens had been forced out from their homes. To measure the pro-social activity in the crisis period, the respondents were asked:

'During the floods in 2014, were you involved in any activity to help the affected area?'

to which they responded either YES or NO. In comparison to the previous question, the number of the respondents who were active in supporting people affected by the floods is higher. Around $70 \%$ of the respondents report that they have provided some support.

Figure 1 below plots the mean values at the municipal level of pro-social activity of individuals in the normal (right) and crisis (left) time in $\mathrm{BiH}$ to create a heat map. Municipalities with a mean value of pro-social activity that lies between 0.8 and 1.0 are black, indicating that between 80 and $100 \%$ of the population has participated in that form of pro-social action. Dark grey municipalities have a mean that lies between 0.6 to 0.8 ; pale white 0.4 to 0.6 ; grey 0.2 to 0.4 and light grey 0.2 and below. The maps clearly show that average levels of pro-social behaviour vary across the municipalities (i.e. not being clustered in particular areas) as we see the colour of the map ranges from black to light grey. It also shows that in many municipalities pro-social behaviour is more prevalent in the period of crisis than in the non-crisis period.

Next, I turn to the measures of structural and relational social capital that I hypothesize to explain individual's propensity to take part in pro-social behaviour. The first dimension of relational social capital is trust. This category includes trust in unknown people - generalised trust (gentrust); trust towards local people - municipal trust (muntrust); and trust in the functioning of institutions - institutional trust (insttrust). The trust variables are almost standardised in the literature and having a long history in empirical studies focused on the 

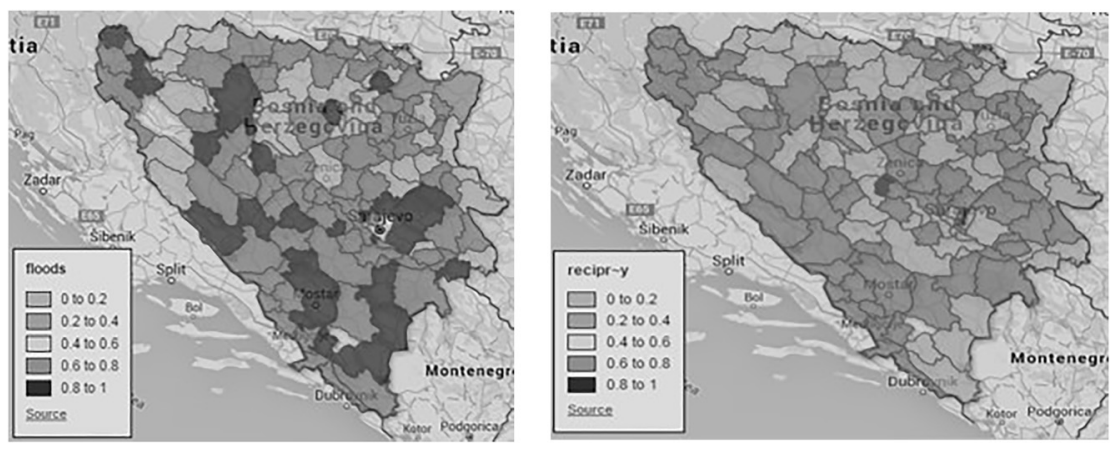

Figure 1. Pro-social activity in crisis and normal periods - Bosnia and Herzegovina

relational social capital. I replicate these questions from the existing studies (e.g. Efendic et al. 2011, 2015), but use a wider scale of responses identified as important through our piloting procedure. The descriptive statistic provides enough indications for a conclusion that the level of any observed type of trust in this society is rather low.

The structural dimension of social capital captures information on the group membership, scope of the network and the internal diversity of network membership (Grootaert et al. 2004). Based on this differentiation, I investigate whether the respondents are 'a member of any group linked to sports, music, arts, political party, NGO, professional and business association, charity, etc.' Majority of the respondents are not active in groups listed in our question, while $13 \%$ of them is a member in a group (group).

Next, I analyse size of the networks in which people are involved in their everyday life activities. I asked the respondents the following question:

'On average, about how many people do you have contact with in a typical day including all those you chat, talk or discuss matters with, whether you do it face-to-face, by telephone, by mail or via the internet and whether you personally know the person or not?'

Majority of the respondents reported that their network size (contsized) is in the range of 520 people.

As I have already pointed out, it is not only the size but also the structure of network that is important to investigate. The database gives us the possibility to analyse internal diversity of networking based on family, friends, acquaintances and other participants. This allows us to investigate the structure of networks in the context of strong and weak ties (strongtie), which is a well-developed approach in the literature (e.g. Greve - Salaff 2003). The obtained results indicate dominance of family and friends (see Table 1). Accordingly, the structure of networks is often based on strong ties (family and friends) rather than weak ties (acquaintances and other people).

Another important issue is the ethnic composition of networks. This network structure is important in the BiH's post-conflict context as it has inherited a number of ethnically related problems and tensions, discussed earlier. More than two decades after the Bosnian War, the country still remains segregated along the ethnic lines, while the three dominant ethnic groups have 
substantial autonomy and control over their own ethno-territorial units (Bieber 2010). In such an environment, people rely on the networks which might be more or less ethnically homogenous, often reflecting ethnic diversity at the local level. Accordingly, I control for the ethnic structure of these networks based on their ethnic diversity (ethcont). I follow Efendic et al. (2015) and ask the respondents what percentage of their network members belong to another ethnicity. $\mathrm{BiH}$ is a multiethnic environment having three dominant ethnicities and more homogenous or heterogeneous networks can have different effects on the pro-social behaviour. The mean value in the sample is $12 \%$, while around $45 \%$ of the respondents report ethnically homogenous networks. This suggests that there is more ethnic homogeneity in the networks than diversity. To investigate the effect of ethnic diversity of the geographic area where the respondents live, I additionally control the type of ethnic composition of the area (ethnically mixed or not, i.e. homogenous).

I include standard individual characteristics, such as age of the respondents (age), gender (male), the level of education (educat), type of geographic area in which they live (urban, suburban, rural and regions: $f b i h, r s b i h, d b b i h)$. I also control for economic characteristics of the respondents since they might be relevant in explaining the pro-social activities that are costly; any social interaction includes some costs (Marmaros - Sacerdote 2006). I include employment status of the respondents distinguishing between formal (femploy) and informal employment (infemploy). One of the characteristics of the $\mathrm{BiH}$ economy is very high official unemployment (around 30\%) and high presence of grey economy (around 30\% according to the latest estimate by Pasovic - Efendic 2018; Efendic et al. 2018). Indeed, in the sample, 34\% of the respondents report having informal jobs or activities that bring them some income.

\section{MODEL SPECIFICATION}

The empirical specification includes pro-social activity - in typical (normality) and in the crisis period (crisis) - as the dependent variable(s) that are affected by social capital. In the model, social capital influences which appear as independent variables include membership in groups and associations (group) and networks in terms of size and structure (contsized, ethncont, strongtie).

There is an issue of possible endogeneity caused by simultaneity problem - that social capital may also be affected by the pro-social behaviour. While membership in groups, the size and structure of networks could explain the pro-social behaviour on the ground, the membership in groups and networks might be encouraged by this pro-social behaviour as well (Bosancianu et al. 2013). However, I believe that this is a less likely scenario, especially in the context of formal membership in different groups that are not happening over the course of a few days, and particularly in the short-run crisis period. In the context of networks, they are built over time and inherited mainly from the past.

I use this data to estimate two probit models (crisis and normality). Both models have appropriate model diagnostics in terms of the model's goodness of fit, which was the initial step in the checking procedure. In general, I find that there is a lot of similarity but also some differences between the determinants affecting social actions of individuals in the normal and crisis period (Table 2, Models 1 and 2). The further check was to test if this difference between Model 1 and Model 2 is systematic (i.e. statistically significant, see Table 1, column 4). There is a structural difference between the estimated coefficients for variables capturing membership in 
groups (group), age (age), gender (male), formal and informal employment (femploy, infemploy) and the type of area (urban). However, I do not discuss these results as the empirical investigation does not stop here but I continue with further investigation.

The decisions on pro-social engagements in the times of crisis and normality are being made by the same individuals, thus I need to take into account that these two outcomes are not independent but may be linked. The Seemingly Unrelated Bivariate Probit Model (SUPM) is a system of equations in which the error terms are allowed to be correlated between equations (Gould et al. 2006), while the common observed determinants are included in both regressions. The SUPM allows for a more complex ('seemingly unrelated') pattern of joint determinations than a 'simple' simultaneity. Hence, the relationship between the respondents' social activities in the typical time and in the crisis time is modelled implicitly through the unobserved correlations in the error terms (Heij et al. 2004), as well as explicitly by controlling for common observable variables in the system. Given that there can be unobserved factors that influence social activities in the typical and crisis periods at the same time, SUPM is an appropriate methodology for this estimation.

The estimated model will enable to test the coefficient from this endogenous system validity with two possible outcomes:

- pro-social activities in the typical and crisis times are not associated in the manner suggested by this model, hence, they are exogenous and should be estimated separately,

- pro-social activities in the typical and crisis periods are endogenously associated in one of the two possible ways:

$\bigcirc$ more pro-social activities in the typical time is associated with more of these type of activities in the crisis time; or

more pro-social activities in the typical time are associated with less of these activities in the crisis time.

I estimate a SUPM with the following specifications:

$$
\begin{gathered}
\text { normality }_{i}=\widehat{\beta}_{1}+X_{K} \dot{s} \widehat{\beta}_{1, K}+\widehat{u}_{1} \\
\text { crisis }_{i}=\widehat{\beta}_{2}+X_{K} \dot{s} \widehat{\beta}_{2, K}+\widehat{u}_{2} \\
\widehat{\rho}=\operatorname{Cov}\left(\widehat{u}_{1}, \widehat{u}_{2}\right)
\end{gathered}
$$

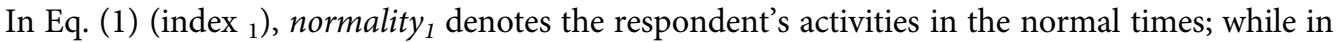
Eq. (2) (index ${ }_{2}$ ) risis ${ }_{2}$ codes the respondent's activity during the floods (crisis) period. $\widehat{\beta}_{1}$ and $\widehat{\beta}_{2}$ are the intercepts in the first and second equations respectively; $\widehat{\beta}_{1, K}, \widehat{\beta}_{2, K}$, are vectors of coefficients to be estimated; $X_{K}$ is a $1 \times k$ vector of $k$ variables that appear in both equations. $\widehat{u}_{1}$ and $\widehat{u}_{2}$ are potentially correlated error terms in the first and second equations respectively and contain unobserved influences that may contribute to the joint determination of pro-social activities. In Eq. (3), the parameter $\widehat{\rho}$ can be interpreted as the correlation between the unobservable explanatory variables of the two equations (Fabbri et al. 2004).

An important issue in analysing survey data is to take into account the survey design. The data was collected using cluster sampling to ensure that individuals from all municipalities were represented in the data. Due to this sampling approach, it is necessary to correct standard errors 
Table 2. Pro-social activities of individuals in typical and crisis period (marginal effects)

\begin{tabular}{|c|c|c|c|c|c|c|}
\hline Variables & $\begin{array}{l}\text { Normal timeProbit } \\
\text { model - exogenous } \\
\text { (Model 1) } \\
\text { dy/dx }\end{array}$ & $\begin{array}{l}\text { Crisis periodProbit } \\
\text { model - exogenous } \\
\text { (Model 2) } \\
\text { dy/dx }\end{array}$ & $\begin{array}{l}\text { Test for difference of } \\
\text { the estimated } \\
\text { coefficients - Model } 1 \\
\text { and Model } 2 \\
\text { P-values }\end{array}$ & $\begin{array}{c}\text { Joint effectsSUPM } \\
\text { 1(Model 3) } \\
\text { dy } / \mathrm{dx}\end{array}$ & $\begin{array}{c}\text { SUPM } 2 \\
(+ \\
\text { Income) } \\
\text { (Model } \\
4) \\
\mathrm{dy} / \mathrm{dx}\end{array}$ & $\begin{array}{c}\text { SUPM 3Parsimionious } \\
\text { model(Model 5) } \\
\text { dy } / \mathrm{dx}\end{array}$ \\
\hline \multicolumn{7}{|c|}{ Social capital - relational and structural } \\
\hline Contsized & $0.07 * * *$ & $0.05 * * *$ & 0.688 & $0.08 * * *$ & $0.06 * * *$ & $0.06 * * *$ \\
\hline Ethncont & $0.01 * * *$ & $0.01^{*}$ & 0.344 & $0.01 * * *$ & $0.01 * * *$ & $0.01 * * *$ \\
\hline Strongtie & $0.01 * *$ & 0.01 & 0.114 & 0.01 & -0.01 & $-0.01 * * \mathrm{Y} 1$ \\
\hline Gentrust & 0.04 & -0.03 & $0.097^{*}$ & 0.01 & 0.01 & 0.01 \\
\hline Muntrust & -0.02 & 0.01 & 0.288 & -0.01 & -0.01 & -0.01 \\
\hline Insttrust & 0.01 & 0.03 & 0.287 & 0.02 & 0.02 & 0.02 \\
\hline \multicolumn{7}{|c|}{ Socio-demographic and individual characteristics } \\
\hline Age & $0.01 * * *$ & 0.01 & $0.003 * * *$ & $0.01 * *$ & $-0.01 * * *$ & $-0.01 * * * \mathrm{Y} 1$ \\
\hline Male & 0.02 & $-0.10 * * *$ & $0.000 * * *$ & $-0.04 * *$ & $-0.05^{* * *}$ & $-0.07 * * * Y 2$ \\
\hline Educat & $0.07 * * *$ & $0.09 * * *$ & 0.195 & $0.10 * * *$ & $0.09 * * *$ & $0.10 * * *$ \\
\hline Femploy & 0.01 & $0.08 * * *$ & $0.002 * * *$ & $0.05 * * *$ & 0.01 & $0.02 * * * \mathrm{Y} 2$ \\
\hline Infemploy & $0.10 * * *$ & 0.01 & $0.001 * * *$ & $0.07 * * *$ & $0.07 * * *$ & $0.07 * * * \mathrm{Y} 1$ \\
\hline Urban & 0.01 & $0.08 * * *$ & $0.004^{* * *}$ & $0.06 * * *$ & $0.06 * * *$ & $0.05 * * * Y 2$ \\
\hline Suburban & 0.01 & 0.02 & 0.590 & 0.01 & 0.02 & 0.02 \\
\hline Fbih & 0.03 & 0.13 & 0.462 & $0.10 * * *$ & $0.09 * * *$ & $0.09 * * *$ \\
\hline
\end{tabular}


Table 2. Continued

\begin{tabular}{|l|c|c|c|c|c|c|}
\hline & $\begin{array}{c}\text { Normal timeProbit } \\
\text { model - exogenous } \\
\text { (Model 1) } \\
\text { Vy/dx }\end{array}$ & $\begin{array}{c}\text { Crisis periodProbit } \\
\text { model - exogenous } \\
\text { (Model 2) } \\
\text { dy/dx }\end{array}$ & $\begin{array}{c}\text { Test for difference of } \\
\text { the estimated } \\
\text { coefficients - Model 1 } \\
\text { and Model 2 } \\
\text { P-values }\end{array}$ & $\begin{array}{c}\text { Joint effectsSUPM } \\
\text { 1(Model 3) } \\
\text { dy/dx }\end{array}$ & $\begin{array}{c}\text { SUPM 2 } \\
\text { Income) } \\
\text { (Model } \\
\text { 4) } \\
\text { dy/dx }\end{array}$ & $\begin{array}{c}\text { SUPM 3Parsimionious } \\
\text { model(Model 5) } \\
\text { dy/dx }\end{array}$ \\
\hline Rsbih & -0.01 & 0.08 & 0.520 & $0.04^{* * *}$ & $0.03^{*}$ & $0.03^{*}$ \\
\hline Mixed & 0.01 & -0.02 & 0.494 & -0.01 & -0.01 & -0.01 \\
\hline Incomeper & - & - & - & - & $0.07^{* * *}$ & $0.07^{* * *}$ \\
\hline $\begin{array}{c}\text { Number of } \\
\text { observations }\end{array}$ & 3,469 & 3,480 & - & 3,457 & 3,079 & 3,457 \\
\hline $\begin{array}{c}\text { Predicted } \\
\text { probability }\end{array}$ & 0.65 & 0.73 & - & 0.50 & 0.49 & 0.50 \\
\hline
\end{tabular}

Note: Statistical significance: ${ }^{* * *}$ is for $1 \%{ }^{* *}$ is for $5 \%$; ${ }^{*}$ is for $10 \%$ level of statistical significance, respectively. ${ }^{\mathrm{Y} 1, \mathrm{Y} 2}$ denote if the variable appears only in the first or second equation, respectively. 
as individuals within the same municipality are likely to have more similarities with each other than with those outside of their municipality. This implies that error terms within clusters will not be independent of each other and I use cluster robust standard errors to ensure that standard errors are not biased.

\section{RESULTS AND DISCUSSION}

Our first step in empirical modelling was to estimate the SUPM model as a cluster-robust model, a model in which clusters are defined as municipalities. As these results are not useful for direct interpretation, I report them in Appendix, Table A.1, and focus this discussion on model diagnostics of these results. The Wald test for the joint significance of the explanatory variables rejects the null hypothesis that the explanatory variables are jointly equal to zero $(P=0.000)$. The Likelihood-ratio (LR) test of the null $\widehat{\rho}=0$ rejects this hypothesis at the highest level $(P=0.000)$. Hence, I reject the null of zero correlation and also the inference that the estimation by separate probit equations is a better strategy. According to the positive correlation coefficient $(\widehat{\rho}=0.17)$, the two dependent variables in Eq. (3) are both determined by unobserved influences that are positively correlated across the two equations. Hence, the general finding of this model is that more pro-social activities of individuals in a typical time is positively $(0.17)$ correlated with more pro-social activities in the period of crisis.

I already mentioned that the coefficients reported in Appendix, Table A1 are not useful for interpretation, however, I estimate marginal effects of each variable on the probability that individuals will report more pro-social activity in the typical time and in the crisis period (when normality $=1$ and crisis $=1$ ). These marginal effects for the baseline model are reported in Table 2 (Model 3), together with marginal effects obtained from separate probit models (Models 1 and 2).

Group membership appears to be the most influential dimension of social capital that contributes both to the pro-social activities of individuals in the typical and in the crisis period. There is a $15 \%$ higher probability that the individuals, who are members of any group linked to sport, music, religion and similar, are systematically reporting more pro-social activities than those who are not members of any group.

Network size is also an important factor - there is around $8 \%$ higher probability that those who have bigger networks (10 members or more) will be more supportive to others in the typical and crisis period than those with smaller network. Hence, the network size is positively associated with the pro-social activities on the ground.

Ethnic diversity of networks, which is of particular interest for this post-conflict society, has a positive effect in the model suggesting that those who report ethnically more diverse networks are more pro-socially engaged in this society, including both the crisis and normal periods. The effect is quite high - e.g. 1\% higher diversity of networks increases the probability of pro-social activity in both the periods in focus by $1 \%$, or $10 \%$ more diverse networks increases the pro-social engagements by $10 \%$. This finding confirms that ethnic diversity is very beneficial for pro-social behaviour of individuals even in the areas where the conflict had an ethnic background.

Contrary to the effect of ethnic diversity of networks, the distinction between strong and weak ties appears as non-significant including all three measures of the relational social capital, i.e. trust in unknown people, in people from the same municipality and trust in institutions. As a 
general conclusion, I identify the importance of structural social capital - both in terms of size of the network and ethnic diversity - but not really a significant effect of the relational capital proxied by trust in people and institutions.

The estimated effects of individual characteristics suggest that the female respondents report (4\%) more pro-social activities than the males. In addition, more educated individuals report more pro-social activities on the ground and having rather high marginal effect in the model of $10 \%$. Consequently, more education is beneficial for social activities of population.

The economic background of the respondents brings us some interesting results. The respondents, who are engaged in informal sector of the economy, report $7 \%$ higher probability of having more pro-social activities than those who are not employed or who are outside of the labour force. Similarly, formal employment increases this probability to 5\%. Further examination was to control for the effect of personal income (Model 4), which is likely to be an endogenous variable, and that is why it is left from the baseline model. However, when I include the level of income, the effect of personal income is around 7\%, while formal employment status losses its significance. Obviously, these variables are capturing similar information - formal employment is a good proxy of personal income. However, informal employment does not change at all. Apparently, formal employment tends to be important in providing the resources for pro-social activities (in particular in the crisis period, Model 2), while informal employment is not affected by the income effect. Finally, the respondents from urban areas report more prosocial activities $(6 \%)$ than those from sub-urban or rural areas.

The models reveal that the group membership, size and ethnic structure of individual networks are the most influential dimensions of social capital, which together with (higher) education and employment status affect the pro-social activities of individuals in this post-conflict environment. Apparently, structural dimensions of social capital in terms of networking have the highest effect in the model. However, the economic determinants, in particular, the type of employment should not be ignored as well. As a new finding, I report that formal and informal economic environment explains the pro-social activities on the ground, where participation in formal economy is more relevant for the pro-social engagement as a source of income.

Following the arguments by Putnam (1993) that the stock of social capital is cumulative, in the next stage I combine different dimensions of social capital and investigate whether they built (i.e. cumulate if combined) in affecting the pro-social activities. I estimate three-way interactions by augmenting the preferred specification from the base-line model with both, the two-way and three-way interactions. I use the full sample in these estimates which are adjusted for multiple comparisons by the Bonferroni method (StataCorp 2011: 1554). This methodology gives us statistically valid identification of effects from the interaction of these variables and takes into account of a rich variety of direct and indirect influences (Efendic et al. 2014). The results reported below are obtained at the highest level of statistical significance.

The general implication that I obtain by interacting different social capital dimensions is that they have important effects in the model not only individually, but in different combinations as well. Hence, the effect of social capital cumulates when it is combined with more dimensions, which confirms Putnam's (1993) argument of cumulative effects of the stock of social capital. For example, while membership in groups increases the pro-social activities by $14 \%$ and networking by $6 \%$, if I combine these two dimensions of social capital, their marginal effect increases to $21 \%$ (group members with larger networks versus non-members with small 
networks). Hence, there is an effect of synergy when different dimensions of social capital are combined.

In order to check the stability of these results, I also estimate the parsimonious models in which I have excluded those variables which are not statistically significant in the main model (Table 1, Model 5), including trust variables (relational social capital proxies), and later, variables measuring formal employment, and ethnic diversity of the respondents' area. In all cases the main results are fully consistent in terms of statistical significance, signs and with similar magnitudes. The coefficient measuring endogenous correlations between the two equations is also statistically significant at the highest level in all estimates and obtains very similar magnitude (0.15). These results confirm stability of the baseline model reported earlier.

\section{LIMITATIONS OF THE RESEARCH}

The primary data are based on a representative survey, thus the responses report perceptions of the respondents, rather than their actual behaviour. This includes their perception of pro-social behaviour, which is a general limitation of such studies. In addition, when I measure pro-social activity, I do not have the possibility to distinguish if the respondents worked as part of a collective or individual action, which is another dimension that some future research might target to investigate. As it is explained in Section 2, social capital means different things to different people and in different disciplines, which is a research challenge that is not easy to tackle.

The internal validity of the two proxies to measure pro-social behaviour in the periods of crisis and normality might have its limitations as well. This is because these two proxies have different time width (one year versus one week) and different chance for being correctly remembered $^{4}$. As I explained in the introduction, this natural disaster was not seen in the modern history of this country, and I believe that the respondents remember quite well what was happening during this crisis time, even if that was a year before. However, some concern always exists.

\section{CONCLUSION}

This study investigated a post-conflict society and how different factors linked to social capital affect the pro-social activities of individuals in two different periods in which the respondents was engaged. These are a typical (normal) and crisis (flood) periods. The research reports that individual involvements in the pro-social activities in these two periods are joint outcomes of a wider system of observed and unobserved (endogenous) influences. They are positively correlated; hence, more pro-social activities of individuals in a typical time are linked with more engagements in the period of crisis. This outcome suggests that building social capital in everyday life is an investment in a more secure positive response of citizens when the society is confronted with sudden challenges, crisis and hurdles.

\footnotetext{
${ }^{4} \mathrm{We}$ thank to anonymous referee for this comment that is integrated into the paper.
} 
The observed determinants in the model reveal that the pro-social activities of citizens are under a strong influence of social capital, but primarily its relational dimension. In particular, I identify that membership in different social groups, more networking of people and more ethnic diversity of individual networking explain the pro-social behaviour. In the context of network structure, I find that ethnic diversity of networks, which is particularly relevant for ethnically mixed societies, is very beneficial for engagement in pro-social behaviour. This result adds to the previous findings of the beneficial effects of ethnic diversity in this post-conflict society; on the growth aspirations of young companies (Efendic et al. 2015) and individual economic performance (Efendic - Pugh 2018). Accordingly, in similar post-conflict environments, investing and supporting ethnic diversity and ethnic tolerance have multidimensional benefits for the society and individuals living in it.

In the context of economic influences examined, I find that participations in informal employment positively affects the pro-social behaviour. Formal employment is important, but it works as a financial intermediary of the pro-social activities.

\section{ACKNOWLEDGEMENTS}

This research was supported by the Regional Research Promotion Programme in the Western Balkans (RRPP), which is run by the University of Fribourg upon a mandate of the Swiss Agency for Development and Cooperation (SDC), Federal Department of Foreign Affairs. I thank to Bojana Babic and Anna Rebmann for their contribution in the initial stage of this paper.

\section{REFERENCES}

Adler, P. S. - Kwon, S. W. (2002): Social Capital: Prospects for a New Concept. Academy of Management Review, 27(1): 17-40.

Aldrich, D. P. (2010): Fixing Recovery: Social Capital in Post-Crisis Resilience. Journal of Homeland and Emergency Security, 7: 1-22.

Aldrich, D. P. (2012): Building Resilience: Social Capital in Post-Disaster Recovery. Chicago: University of Chicago Press.

Bieber, F. (2010): Bosnia and Herzegovina since 1990. In: Ramet, S. P. (ed.): Central and Southeast European Politics Since 1989, pp. 311-328. Cambridge: Cambridge University Press.

Bierhoff, H. W. (2002): Prosocial Behaviour. Psychology Press, Hove, East Sussex.

Bosancianu, C. M. - Powell, S. - Bratović, E. (2013): Social Capital and Pro-Social Behavior Online and Offline. International Journal of Internet Science 8(1), 49-68.

Bourdieu, P. (1980): Le Capital Social. Actes de la Recherche en Sciences Sociales, 31: 2-3.

Bourdieu, P. (1986): The Forms of Capital. In: Richardson, J. G. (ed.): Handbook of Theory and Research for the Sociology of Education, pp. 241-258. Westport: Greenwood Publishing Group.

Burt, R. S. (1992): In: The Social Structure of Competition. Harward University Press, Cambridge, MA. Coleman, J. S. (1988): Social Capital in the Creation of Human Capital. American Journal of Sociology, 94: S95-S120. 
Dabrowski, M. - Myachenkova, Y. (2018): The Western Balkans: Weak Performance since the Crisis. Acta Oeconomica 68(2): 85-120.

Durlauf, S. N. (2002): On the Empirics of Social Capital. The Economic Journal, 112(November): 459-479.

Dyrstad, K. (2012): After Ethnic Civil War - Ethno-Nationalism in the Western Balkans. Journal of Peace Research, 49(6): 817-831.

Edwards, R. - Franklin, J. - Holland, J. (eds) (2006): Assessing Social Capital: Concept, Policy and Practice. London: Taylor and Francis.

Efendic, A. - Ledeneva, A. (2020): The Importance of Being Networked: Costs of Informal Networking in the Western Balkans. Economic Systems (Forhtcoming).

Efendic, A. - Mickiewicz, T. - Rebmann, A. (2015): Growth Aspirations and Social Capital : Young Firms in a Post-Conflict Environment. International Small Business Journal, 33(5): 537-561.

Efendic, A. - Pugh, G. - Adnett, N. (2011): Confidence in Formal Institutions and Reliance on Informal Institutions in Bosnia and Herzegovina - An Empirical Investigation Using Survey Data. Economics of Transition, 19(3): 521-540.

Efendic, A. - Silajdzic, S. - Atanasovska, V. (2014): Ethnic Tensions and Economic Performance: Bosnia, Herzegovina and Macedonia. Saarbrücken: Lambert Academic Publishing.

Efendic, A. - Pugh, G. (2018): The Effect of Ethnic Diversity on Income - An Empirical Investigation Using Survey Data from a Post-Conflict Environment. Economics: The Open-Access, Open-Assessment EJournal, 12(2018-17): 1-34. Http://Dx.Doi.Org/10.5018/Economics-Ejournal.Ja.2018-17.

Efendic, N. - Pasovic, E. - Efendic, S. A. (2018): Understanding Informal Economy in Practice - Evidence from Bosnia and Herzegovina. Financial Internet Quarterly "E-Finanse", 14(4): 77-89.

Fabbri, D. - Monfardini, C. - Radice, R. (2004): Testing Exogeneity in the Bivariate Probit Model: Monte Carlo Evidence and an Application to Health Economics. Dipartimento Scienze Economiche: Universitá di Bologna, Working Papers, No. 514.

Gould, W. - Pitblado, J. - Sribney, W. (2006): Maximum Likelihood Estimation with Stata. Stata Press.

Granovetter, M. (1973): The Strength of Weak Ties. American Journal of Sociology, 78(3): 1360-1380.

Granovetter, M. (1992): Problems of Explatations in Economic Sociology. In: Norhia, N. - Eccles, R. (eds): Networks and Organizations: Structure, Form and Action, pp. 25-26. Boston: Harward Business School Press.

Greve, A. - Salaff, J. W. (2003): Social Networks and Entrepreneurship. Entrepreneurship Theory and Practice, 28(1): 1-22.

Grootaert, C. - Narayan, D. - Jones, V. N. - Woolcock, M. (2004). Measuring Social Capital: An Integrated Questionnaire. Working Paper, No. 18. World Bank, Washington, D.C.

Grossman, G. M. (2013): Developing Social Capital through National Education: The Transformation of Teacher Education in Turkey. In: Saleh, I. M. - Khine, M. S. - Haslam, I. R. (eds): Large Scale Reform and Social Capital Building, pp. 127-140. New York: Routledge.

Hakansson, P. - Sjoholm, F. (2007): Who Do You Trust? Ethnicity and Trust in Bosnia and Herzegovina. Europe-Asia Studies, 59(6): 961-976.

Heij, C. - De Boer, P. - Franses, P. H. - Kloek, T. - Van Dijk, H. K. (2004): Econometric Methods with Applications in Business and Economics. Oxford: Oxford University Press.

Helliwell, J. F. - Aknin, L. B. - Shiplett, H. - Huang, H. - Wang, S. (2018): Social Capital and Prosocial Behavior as Sources of Well-Being. In: Diener, S. O. - Tay, L. (eds.), Handbook of Well-being. DEF Publishers, Salt Lake City.

Kaasa, A. (2009): Effects of Different Dimensions of Social Capital on Innovative Activity: Evidence from Europe at the Regional Level. Technovation, 29(3): 218-233. 
Knack, S. - Keefer, P. (1997): A Survey of Cross-Country Evidence. Social Capital Initiative. World Bank Working Paper, No. 7.

Lesage, J. P. - Ha, C. L. (2012): The Impact of Migration on Social Capital: Do Migrants Take Their Bowling Balls with Them? Growth and Change, 43(1): 1-26.

Malcolm, N. (1996): Bosnia - A Short History. NY: New York University Press.

Marmaros, D. - Sacerdote, B. (2006): How Do Friendships Form? The Quarterly Journal of Economics 121(1): 79-119.

Nahapiet, J. - Ghoshal, S. (1998): Social Capital, Intellectual Capital, and the Organizational Advantage. Academy of Management Rreview, 23(2): 242-266.

Nooteboom, B. (2007): Social Capital, Institutions and Trust. Review of Social Economy, 65(1): 29-53.

Ostrom, E. (2001): Social Capital: A Fad or a Fundamental Concept? In: Dasgupta, P. - Serageldin, I. (eds): Social Capital: A Multifaceted Perspective, pp. 172-214. Washington, D.C.: World Bank Publications.

Pasovic, E. - Efendic, A. (2018): Informal Economy in Bosnia and Herzegovina - An Empirical Investigation. South East European Journal of Economics and Business, 13(2): 112-125.

Portes, A. (1998): Social Capital: Its Origins and Applications in Modern Sociology. Annual Review of Sociology, 24: 1-24.

Putnam, R. D. (1993): The Prosperous Community. The American Prospect, 4(13): 35-42.

Putnam, R. D. (1995): Bowling Alone: America's Declining Social Capital. Journal of Democracy, 6(1): 65-78.

Putnam, R. D. (2000): Bowling Alone: America's Declining Social Capital. In: Crothers, L. - Lockhart, C. (eds): Culture and Politics, pp. 223-234. New York: Palgrave Macmillan.

Rebmann, A. - Efendic, A. - Mickiewicz, T. (2017): Nascent Enterprises and Growth Aspirations in a PostConflict Environment: The Role of Social Capital. In: Williams, C. - Gurtoo, A. (eds): Routledge Handbook of Entrepreneurship in Developing Economies, pp. 70-89. Oxon and NY: Routledge.

Robison, L. J. A. - Schmid, A. - Siles, M. E. (2002): Is Social Capital Really Capital? Review of Social Economy, LX(1): 1-21.

Rose, R. (1999): Making Openness Work. Baltimore, Md: John Hopkins University Press.

Savioli, M. - Patuelli, R. (2016): Social Capital, Institutions and Policymaking. Economics Discussion Papers, No. 2016-26, Kiel Institute for the World Economy.

Sobel, J. (2002): Can We Trust Social Capital? Journal of Economic Literature, XL(March): 139-154.

Sopha, A. - Oeur, I. - Mcandrew, J. (2007): Understanding Social Capital in Response to Floods and Droughts. Cambodia Development Review, 11(4): 9-12.

UNDP (2007): The Silent Majority Speaks. UNDP BiH, Sarajevo.

UNDP (2009): The Ties that Bind - Social Capital in Bosnia and Herzegovina. National Human Development Report 2009. UNDP BiH, Sarajevo.

Wang, C. L. - Altinay, L. (2012): Social Embeddedness, Entrepreneurial Orientation and Firm Growth in Ethnic Minority Small Business in the UK. International Small Business Journal, 30(1): 3-23.

Whitt, S. (2010): Institutions and Ethnic Trust: Evidence from Bosnia. Europe-Asia Studies, 62(2): 271-292. Woolcock, M. (1998): Social Capital and Economic Development: Toward a Theoretical Synthesis and Policy Framework. Theory and Society, 27(2): 151-208. 


\section{APPENDIX}

Table A.1. Results from the baseline SUPM model (cluster-robust inference)

\begin{tabular}{|c|c|c|c|c|c|c|c|c|}
\hline \multirow{3}{*}{$\begin{array}{l}\text { The depende } \\
\text { free) } \\
\text { The depende } \\
\text { Variable }\end{array}$} & \multicolumn{8}{|c|}{$\begin{array}{l}\text { t variable in the first equation: normality }(0=\text { not helping others; } 1=\text { helping others for } \\
\text { t variable in the second equation: crisis ( } 0=\text { not helping; } 1=\text { helping during the floods) }\end{array}$} \\
\hline & \multicolumn{4}{|c|}{ Normal period activity } & \multicolumn{4}{|c|}{ Crisis period activity } \\
\hline & Coeff. & Robust SE & z-stat. & $P>|t|$ & Coeff. & Robust SE & z-stat. & $P>|t|$ \\
\hline \multicolumn{9}{|c|}{ Social capital - relational and structural } \\
\hline Group & 0.24 & 0.07 & 3.33 & 0.001 & 0.42 & 0.08 & 5.53 & 0.000 \\
\hline Contsized & 0.14 & 0.05 & 2.92 & 0.003 & 0.12 & 0.05 & 2.45 & 0.014 \\
\hline Ethncont & 0.01 & 0.01 & 3.35 & 0.001 & 0.01 & 0.01 & 2.11 & 0.034 \\
\hline Strongtie & -0.01 & 0.01 & -1.81 & 0.071 & -0.01 & 0.01 & -0.16 & 0.870 \\
\hline Gentrust & 0.08 & 0.09 & 0.96 & 0.338 & -0.06 & 0.09 & -0.76 & 0.446 \\
\hline Muntrust & -0.05 & 0.07 & -0.71 & 0.479 & 0.03 & 0.07 & 0.44 & 0.663 \\
\hline Insttrust & 0.01 & 0.06 & 0.03 & 0.974 & 0.07 & 0.06 & 1.17 & 0.241 \\
\hline \multicolumn{9}{|c|}{ Socio-demographic and individual characteristics } \\
\hline Age & -0.01 & 0.01 & -2.70 & 0.007 & 0.01 & 0.01 & 1.22 & 0.224 \\
\hline Male & 0.06 & 0.05 & 1.24 & 0.214 & -0.27 & 0.05 & -5.42 & 0.000 \\
\hline Educat & 0.18 & 0.06 & 2.78 & 0.005 & 0.30 & 0.07 & 4.59 & 0.000 \\
\hline Femploy & 0.03 & 0.06 & 0.61 & 0.539 & 0.26 & 0.06 & 4.57 & 0.000 \\
\hline Infemploy & 0.26 & 0.05 & 4.82 & 0.000 & 0.02 & 0.06 & 0.29 & 0.774 \\
\hline Urban & 0.05 & 0.06 & 0.85 & 0.394 & 0.28 & 0.07 & 3.86 & 0.000 \\
\hline Suburban & 0.02 & 0.06 & 0.34 & 0.737 & 0.07 & 0.06 & 1.02 & 0.309 \\
\hline Fbih & 0.04 & 0.04 & 0.96 & 0.338 & 0.35 & 0.05 & 7.84 & 0.000 \\
\hline Rsbih & -0.03 & 0.05 & -0.65 & 0.518 & 0.24 & 0.05 & 4.59 & 0.000 \\
\hline Mixed & -0.01 & 0.06 & -0.19 & 0.852 & -0.04 & 0.05 & -0.90 & 0.366 \\
\hline Cons & 0.01 & 0.15 & 0.04 & 0.964 & -0.49 & 0.15 & -3.31 & 0.001 \\
\hline \multicolumn{9}{|c|}{ Model diagnostics } \\
\hline \multicolumn{5}{|c|}{ Number of obsenvations } & \multicolumn{4}{|c|}{3,457} \\
\hline \multicolumn{5}{|c|}{ Coefficient of correlation in the residuals } & \multicolumn{4}{|c|}{$\widehat{\rho}=0.17$} \\
\hline \multicolumn{5}{|c|}{ The Likelihood-ratio test of $\widehat{\rho}=0$} & \multicolumn{4}{|c|}{$z=5.08 ;$ Prob $>|Z|=0.000$} \\
\hline \multicolumn{5}{|c|}{ The Wald test for joint significance } & \multicolumn{4}{|c|}{$\operatorname{chi}^{2}(38)=878 ;$ Prob $>$ chi $^{2}=0.000$} \\
\hline
\end{tabular}

Source: Author's calculations using STATA 12 (STATA 12, StataCorp, Texas, USA). 